\title{
Using Dental Metrical Analysis to Determine the Terminal Pleistocene and Holocene Population History of Java
}

\author{
Sofwan Noerwidi
}

The Song Keplek 5 burial from Java, initially dated to the early Holocene from charcoal in the grave fill, has now been directly dated to around 3000 BP. Bivariate and multivariate analyses of its lower premolar and molar diameters demonstrates affinities with recent Javanese and Malays, whereas other Java burials dated to between the terminal Pleistocene and mid-Holocene have greater dental metrical similarities with recent Australians and Melanesians. This finding is consistent with Peter Bellwood's argument that the major component of the late Holocene gene pool of Indo-Malaysians can be attributed to a migration of Austronesian-speaking southern Mongoloids' from Taiwan into Island Southeast Asia at around 4000 BP. However, there may also have been later exogenous inputs into the gene pool of the Javanese, as suggested by their Y-chromosome diversity and implied here by analysis of the lower dental metrics of some of the Batujaya burials from Java's protohistorical period.

\section{Introduction}

Java is of strategic importance for registering the dispersal of anatomically modern humans across the region that is today Island Southeast Asia (ISEA) and further on into the Pacific. Prior to the Holocene rise in sea levels that separated Java from Sumatra, the Malay Peninsula and Kalimantan (Borneo), Java was part of the Late Pleistocene subcontinent known as Sundaland. The Homo sapiens fossil record in Java may date back to as early as 125,000 BP, based on the proposed dating for the Punung (Gunung Sewu) rainforest fauna (Sémah et al. 2006; Westaway et al. 2007), which includes a human premolar crown with diameters of $H$. sapiens rather than H. erectus size (Storm et al. 2005). More definitive evidence of early H. sapiens in Java is presented by the Wajak burials, minimally dated to 28,000 BP (Storm et al. 2013), still somewhat younger than the ca.35,000 BP directly dated human remains from Niah (Borneo), and the colonisation of Australia and Melanesia between ca. 50,000 and 60,000 BP (Reynolds et al. 2013). Fossil remains of the terminal Pleistocene to mid-Holocene hunter-gatherer occupants of Java are preserved within the habitation sequences of the Gunung Sewu caves and Gua Pawon. Late Holocene colonisation events associated with the dispersal of Austronesian languages across ISEA and much of the Pacific, and the introduction of Indic culture to protohistorical Java, are potentially registered in the human remains from cemetery sites such as Batujaya and Plawangan. 
There has been considerable debate over the origins of the Austronesian languages and the significance of the dispersal of these languages for the gene pool of present-day Island Southeast Asians. Lexicostatistical analysis by Isidore Dyen originally suggested an origin in Melanesia, and John Terrell has perpetuated the notion of Melanesias importance for understanding developments in ISEA with his proposal that the two regions constitute an 'entangled bank' (see Chambers 2006). Solheim (2006: 90-92) noted that shell tools were reconstructed by linguists as an aspect of proto-Austronesian material culture, and accordingly located the protoAustronesian homeland in the northern Moluccas, the centre of distribution of shell adzes extending from the Bismarcks into eastern Indonesia, the Ryukyus and Western Micronesia. This view is consistent with the craniometric analysis of Pietrusewsky (2006), which finds that Southeast Asians constitute a discrete, homogeneous group. However, the most widely accepted proposal is that the Austronesian languages originated in Taiwan, prior to their dispersal across ISEA and the smaller and more remote islands of the Pacific, facilitated by their advanced watercraft and fuelled by the agricultural component of their subsistence economy (Blust 1976; Bellwood 1995). Bellwood (1997) further proposes that the ancestors of the protoAustronesians were agricultural 'Mongoloids' located in southern China, and their absorption of the indigenous ISEA foragers resulted in ISEA's 'Southern Mongoloid' racial type. According to Bellwood's 'Out of Taiwan' theory, initial expansion from Taiwan commenced at about $4000 \mathrm{BP}$ and extended across ISEA by 3000 BP, as registered by the appearance of Neolithic sites and associated material culture.

A more complicated scenario has recently been proposed by Karafet et al. (2010) based on their analysis of Indonesian Y-chromosome diversity. There were two Late Pleistocene colonisation events into Sundaland, an 'A' event associated with the dispersal of $H$. sapiens from Africa to Australia and Melanesia at around 50,000 BP, and a 'B' event in which terminal Pleistocene foragers from Mainland Southeast Asia migrated south into Sundaland. The ' $C$ ' and ' $D$ ' events in Indonesia's population history correspond to the 'Out-of-Taiwan' migration, and to protohistorical inputs from India into Sumatra and Java and from North Vietnam into Borneo, respectively.

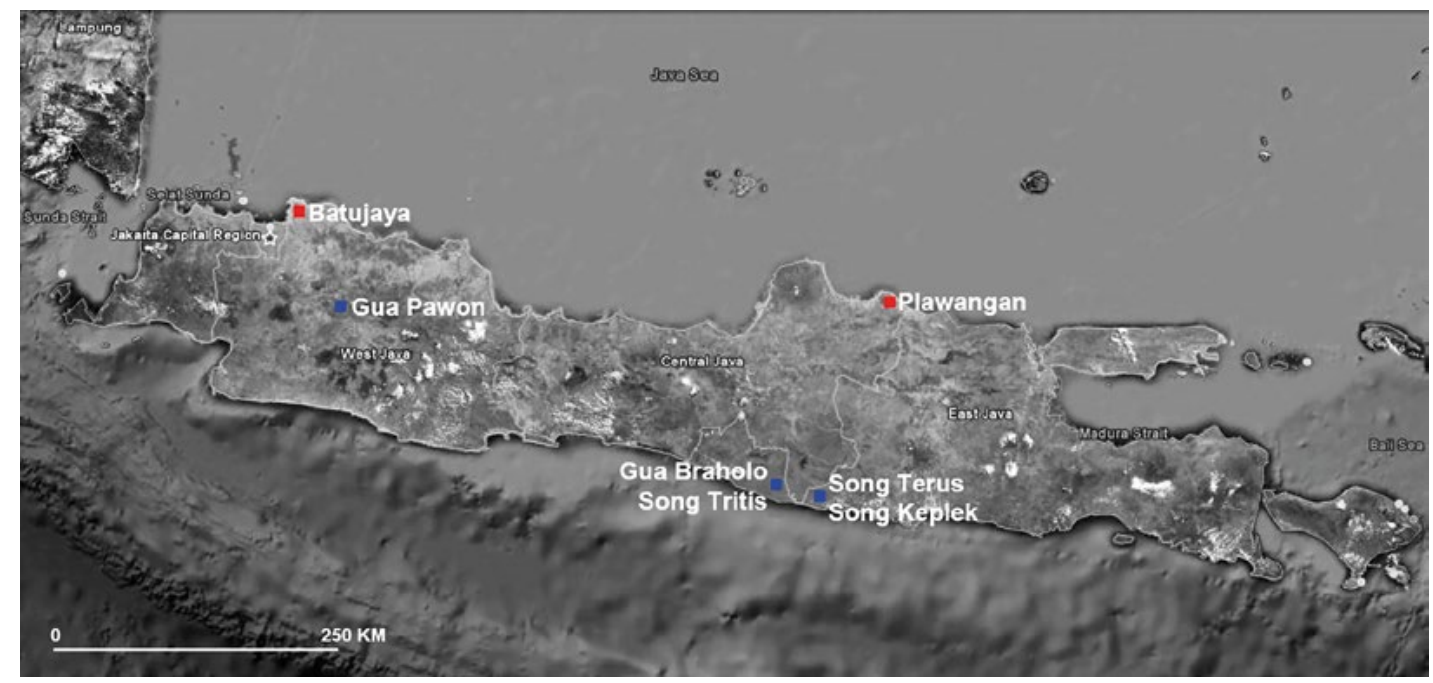

Figure 5.1 Map of Java showing locations of the studied specimens. Blue: Pre-Neolithic sites, Red: Palaeometallic sites.

Source: Google Maps with modification by S. Noerwidi. 
One of the critical burials for testing the various scenarios described above is Song Keplek 5 from the Gunung Sewu caves in Java (Figure 5.1). Initially it was dated to $7020 \pm 180$ BP on charcoal from the grave fill, but the features of the skull pointed to a Mongoloid affinity (Détroit 2002; Widianto 2006). The Mongoloid identification conflicted with the 'AustraloMelanesian' morphology described for other early to mid-Holocene human remains from ISEA, and also cast doubt on scenarios that associated a Mongoloid presence in ISEA with the late Holocene migration of Austronesian speakers from Taiwan. However, as detailed below, direct dating of the Song Keplek 5 burial places it within the timeframe for the 'Out-of-Taiwan' migration and not within the mid-Holocene prehistory of the island. Accordingly, one of the key predictions of the 'Out-of-Taiwan' theory - a dichotomy between Australo-Melanesians dating to the mid-Holocene and earlier, and Mongoloids dating to the late Holocene - retains its viability for testing against the Java human skeletal record. For further details on the study presented here, see the author's Erasmus Mundus Master's thesis (Noerwidi 2011/12), from which this contribution is extracted and adapted.

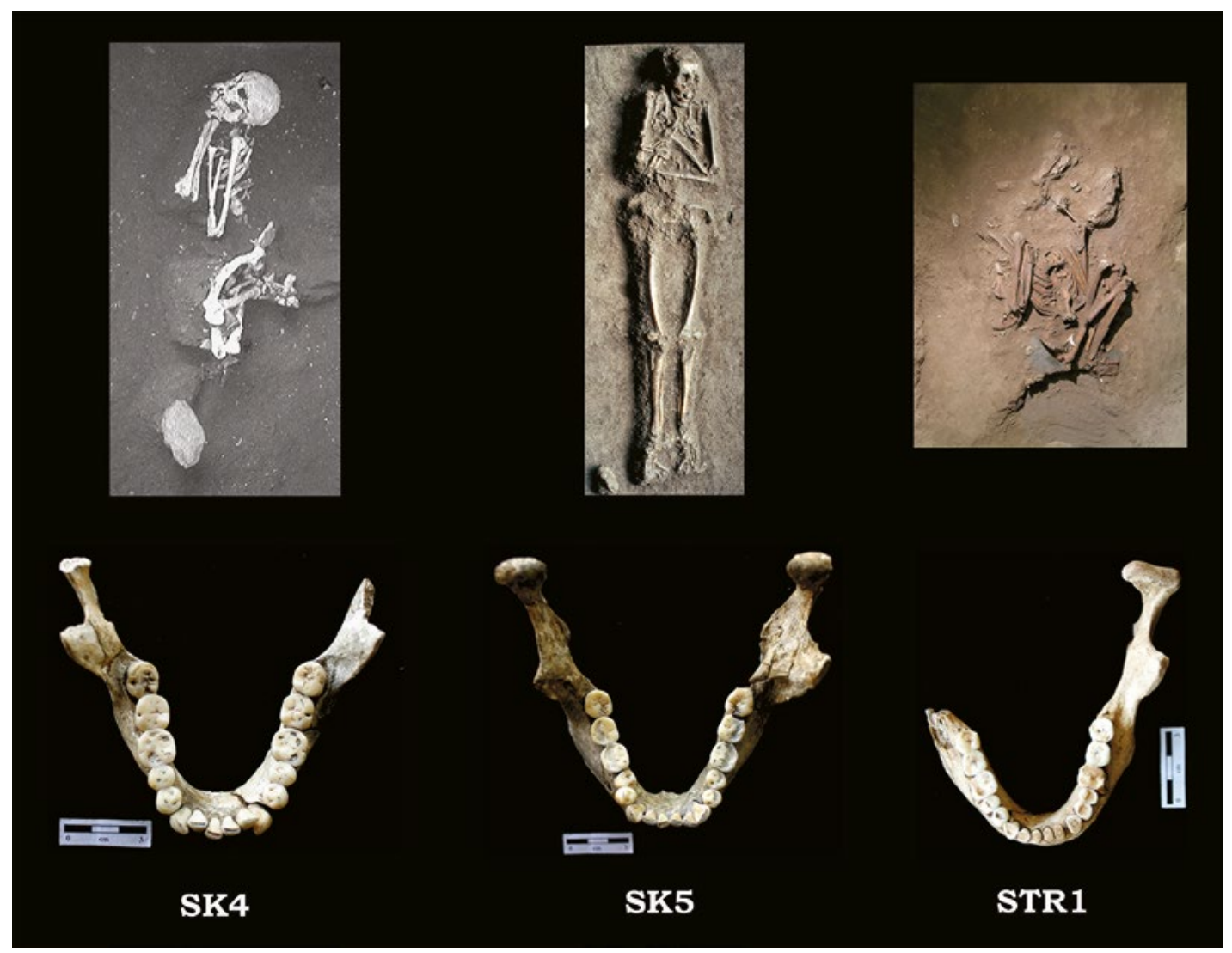

Figure 5.2 Human remains with the mandibles discovered at Song Keplek and Song Tritis sites. Source: Photographs of SK4, SK5 and STR1 in situ by Détroit (2002); kind permission by H.T. Simanjuntak and F. Détroit, others by S. Noerwidi.

\section{Materials and methods}

The author's original study (Noerwidi 2011/12) focused on Song Keplek 5 and in particular its mandible and lower teeth, which are the best preserved parts of the skull (Figure 5.2). The critical comparisons lie with other specimens from Java's human skeletal record, which led to the decision to include a focus on the premolars and first and second molars, as these are 
usually better preserved than the other lower teeth. As described below, the Java archaeological specimens available for comparison are dated to between the terminal Pleistocene and the early centuries AD (Table 5.1). To test the predicted Australo-Melanesian affinities of the pre3500 BP Java fossils, versus the predicted Southern Mongoloid affinities of the post-3500 BP archaeological specimens, the lower premolars and molars were also recorded for 51 recent Australian, Melanesian and ISEA mandibles collected by seventeenth- to nineteenth-century French naturalists. These mandibles, held at the Paris Museum of Natural History, include four Tasmanians, four mainland Australians, three Torres Strait Islanders, one Papuan, six Solomon Islanders and three Fijians (21 Australo-Melanesians), as well as 20 Javanese and 10 Malays (30 Southeast Asians).

In addition to Song Keplek 5, four other specimens from four sites in the Gunung Sewu region of East Java were available for analysis (Figure 5.1). None of them are directly dated and this attaches some doubt to the reliability of their age indicated in Table 5.1, when we consider that direct dating of Song Keplek 5 reduced its antiquity by approximately 4,000 years compared to its age as implied by charcoal from the grave fill. However, from the available age estimates, Song Tritis 1 would be predicted to align with Song Keplek 5 in showing Southern Mongoloid affinities, whereas Song Keplek 4, Song Terus 1 (Figure 5.2) and Gua Braholo 5 should show Australo-Melanesian affinities. An Australo-Melanesian affinity would also be expected for two specimens from Gua Pawon, in West Java, which are directly dated to the terminal Pleistocene and early Holocene, respectively. Fifteen specimens dated to within the last 2,000 years or so together represent the two open-air cemetery sites of Baturaja and Plawangan on Java's north coast. Their predicted affinities would be predominantly Southern Mongoloid, although the pronounced, early Indian influence documented at Batujaya (Manguin and Indradjaja 2011) makes the skeletal remains of particular interest for registering the ' $\mathrm{D}$ ' event in the multi-stage colonisation scenario of Karafet et al. (2010).

Table 5.1 Archaeological specimens from Java (Figure 5.1) used in this study.

\begin{tabular}{|c|c|c|c|c|}
\hline ID & Specimen & Dating & $\begin{array}{l}\text { Calibrated date cal.BP } \\
\text { (at } 2 \text { s.d) }\end{array}$ & $\begin{array}{l}\text { Laboratory/Literature } \\
\text { reference }\end{array}$ \\
\hline BHL5 & Gua Braholo 5 & $\begin{array}{l}13,290 \pm 400 \mathrm{BP} \text { (charcoal at same } \\
\text { stratigraphic level) }\end{array}$ & $17,328-14,768(95 \%)$ & P3G 1998 (Simanjuntak 2002) \\
\hline ST1 & Song Terus 1 & $9330 \pm 90$ BP (shellfish in grave fill) & $\begin{array}{l}\text { Calibration } \\
\text { inappropriate }\end{array}$ & $\begin{array}{l}\text { Beta } 124011 \text { (Sémah et al., } \\
\text { 2004) }\end{array}$ \\
\hline SK4 & Song Keplek 4 & $4510 \pm 90$ BP (charcoal in grave fill) & $\begin{array}{l}5378-4921(90.5 \%) \text { or } \\
5498-5437(4.9 \%)\end{array}$ & $\begin{array}{l}\text { Beta } 69689 \text { (Simanjuntak } \\
\text { 2002) }\end{array}$ \\
\hline SK5 & Song Keplek 5 & $\begin{array}{l}3053 \pm 65 \text { BP (direct date on } \\
\text { human bone) }\end{array}$ & $3450-3116(95.4 \%)$ & AA96775 (Noerwidi 2011/12) \\
\hline STR1 & Song Tritis 1 & $\begin{array}{l}\text { ca. } 3000 \text { BP (estimated age based } \\
\text { on material culture) }\end{array}$ & No dates & Widianto 2001 \\
\hline Paw5 & Gua Pawon 5 & $\begin{array}{l}9525 \pm 200 \mathrm{BP} \text { (direct date on } \\
\text { human bone) }\end{array}$ & $11,342-10,301(95.4 \%)$ & P3TIR, BATAN 2004 (this paper) \\
\hline Paw4 & Gua Pawon 4 & $\begin{array}{l}7320 \pm 180 \mathrm{BP} \text { (direct date on } \\
\text { human bone) }\end{array}$ & 8510-7839 (94.9\%) & P3TIR, BATAN 2004 (this paper) \\
\hline Bat & $\begin{array}{l}\text { Batujaya; } 8 \\
\text { specimens }\end{array}$ & 1998_34 (charcoal from cemetery) & $\begin{array}{l}2060-1923(92.8 \%) \text { or } \\
2091-2071(2.6 \%)\end{array}$ & $\begin{array}{l}\text { Wk-21319 (Manguin and } \\
\text { Indradjaja 2011) }\end{array}$ \\
\hline Pla & $\begin{array}{l}\text { Plawangan; } \\
7 \text { specimens }\end{array}$ & $\begin{array}{l}\text { Early centuries AD (estimated from } \\
\text { associated material culture) }\end{array}$ & No reliable dates & Bintarti 2000 \\
\hline
\end{tabular}

Source: Dates calibrated with Intcal 13 (0xcal 4.2; Bronk Ramsey 2014). 
The tooth measurements collected for this study and analysed here are the maximum mesiodistal (M-D) length and bucco-lingual (B-L) breadth of the left-side premolars and the first and second molars. Recent Australo-Melanesians have larger average tooth size than recent Southeast Asians, including Malays and Javanese, as well as 'shape' differences in the relative size of the tooth diameters to each other, after removing the size difference effects (Matsumura and Hudson 2005). Principal Components Analysis (PCA) is a useful statistical tool to detect patterns in both tooth size and shape as it compresses the data by reducing the number of dimensions with little loss of information. In particular, the first principal component usually reflects size differences when biological data are analysed, while the other components reflect different, statistically independent aspects of shape (Joliffe 2002). However, the PCA results produce scattergrams that do not clearly specify the relationships of the studied specimens to each other. To achieve that outcome, the Euclidean distances between each pair of specimens were calculated and the specimens were grouped together using hierarchical, agglomerative clustering.

This particular procedure groups the most similar specimens into pairs, and then either groups other similar specimens with these pairs or else groups together similar pairs, progressively adding less similar specimens or groups until all of the original specimens have been included within a single large cluster (Holland 2006).

Two caveats should be mentioned that may obscure complete confirmation of the hypothesised expectations (see Snell 1949; Brown 1989). The first caveat is that males tend to have larger teeth than females. Accordingly, male and female samples of groups with larger teeth and groups with smaller teeth will tend to overlap more with each other than if the compared samples were restricted just to males or females. In the present study, male and female samples were used because of the unreliability of assigning sex to mandibles, even though this contributes sex-based variability to the tooth sizes of the compared groups. The second caveat is that tooth wear during life includes a component known as interstitial wear, caused by the friction between adjacent teeth in the tooth-row, which pares back the mesio-distal lengths of the adjacent teeth. Particularly in the case of elderly individuals from populations that experienced heavy wear - notably, populations that practised traditional foraging - the mesio-distal lengths are systematically reduced compared with the bucco-lingual widths. The implications for the present analysis are the potential for specifically reduced tooth lengths and decreased overall tooth size for some of the forager specimens.

Accordingly, Bellwood's (1997) scenario of Southern Mongoloid immigration into ISEA after $3500 \mathrm{BP}$ entails the four, following testable predictions for the tooth measurements collected for this study.

1. When the M-D and B-L diameters for the premolars and molars are graphed, these should tend to be larger for the pre-Neolithic Java fossils and recent Australo-Melanesians than the Neolithic to recent Javanese and Malays.

2. This difference in tooth-size trends should also be revealed by the first principal component of the PCA.

3. The second and third components of the PCA should reveal tooth-size shape differences distinguishing pre-Neolithic Java fossils and recent Australo-Melanesians from Neolithic and later Javanese and Malays.

4. The cluster analysis should identify discrete clusters of pre-Neolithic Java and recent Australo-Melanesian specimens on the one hand and Neolithic to recent Javanese and Malays on the other hand. 


\section{Results}

\section{Bivariate Analyses}

In Figures 5.3 to 5.6, the left mesio-distal diameters of the lower first premolar $\left(\mathrm{P}_{3}\right)$, second premolar $\left(\mathrm{P}_{4}\right)$, first molar $\left(\mathrm{M}_{1}\right)$ and second molar $\left(\mathrm{M}_{2}\right)$ are plotted on the $\mathrm{X}$-axis, and the left bucco-lingual diameters are plotted on the Y-axis. In three of the plots (Figures 5.3, 5.4 and 5.6), there are recent Australo-Melanesians with larger teeth than any recorded for recent Southeast Asians, and recent Southeast Asians with smaller teeth than any recorded for recent AustraloMelanesians. There is also considerable overlap between the Australo-Melanesian and Southeast Asian ranges of variation, but this is presumably due in part to comparing female AustraloMelanesians with male Southeast Asians. However, the overlap is so pronounced for the first molar (Figure 5.5) that it is difficult to ascertain whether the recent Australo-Melanesians and Southeast Asians recorded for this study show any apparent difference in first lower molar size.

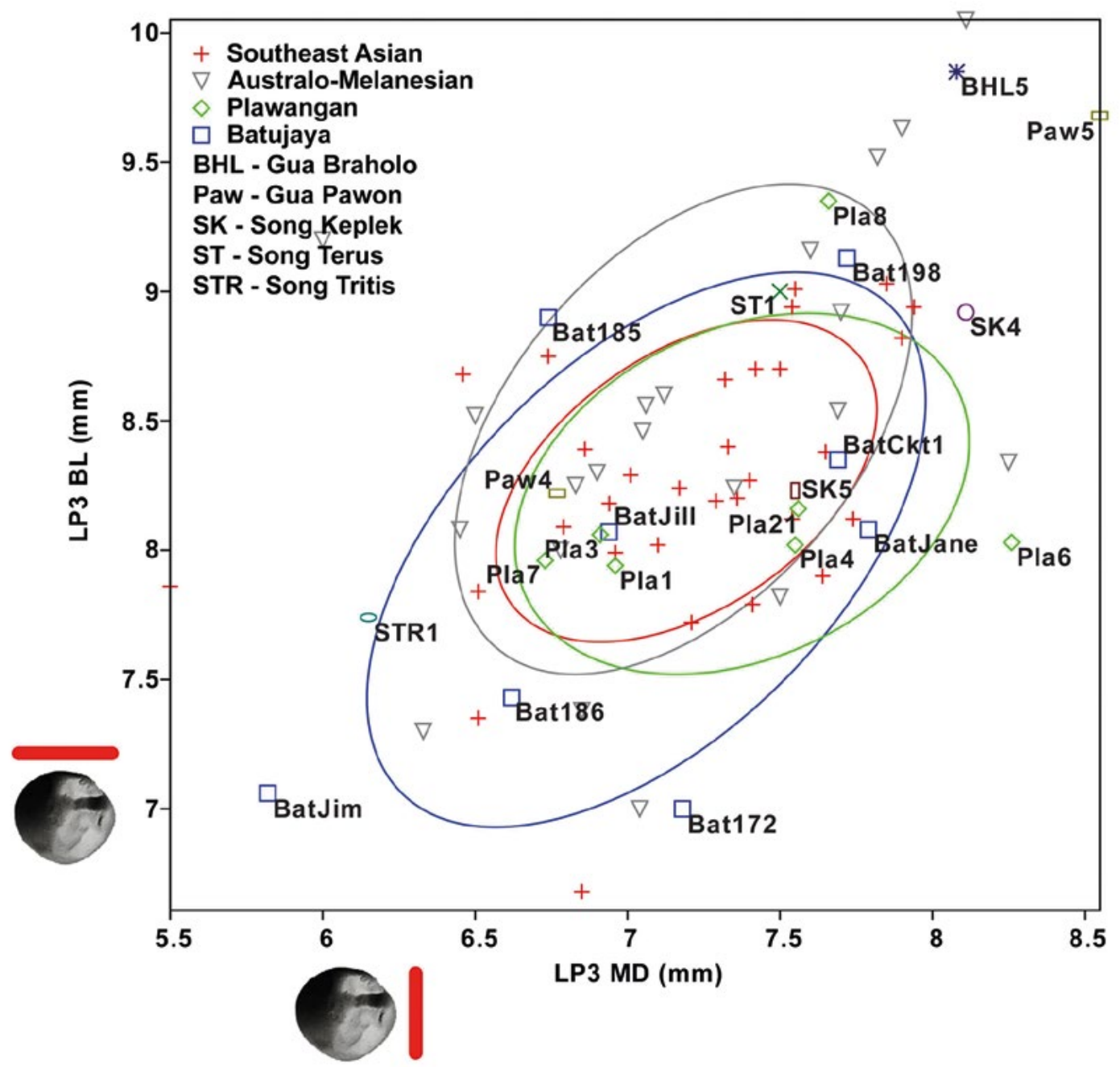

Figure 5.3 Bivariate plot of mesio-distal versus bucco-lingual measurements for $\mathrm{LP}_{3}$. Source: S. Noerwidi. 
Most of the pre-Neolithic Java specimens show large premolars and/or molars. Paw5 has tooth diameters that fall above the recent Southeast Asian range or, in the case of the fourth premolar (Figure 5.4), just within it. ST1 and SK4 have molar diameters that fall above the recent Southeast Asian range and premolar diameters that are large by recent Southeast Asian standards, albeit within the range. BLH5 has premolar diameters that fall above the recent Southeast Asian range, although its molar diameters would be typical by recent Southeast Asian standards. It may also be noted that these pre-Neolithic Java specimens have tooth diameters that consistently fall within the recent Australo-Melanesian range, except for the first molar, where the diameters of SK4 and Paw5 are actually larger than any recorded here for Australo-Melanesians. However, it should be noted that one of the pre-Neolithic Java specimens, Paw4, has tooth diameters that either fall within the recent Southeast Asian range or, in the case of the first molar, lie very close (Figures 5.3 to 5.6).

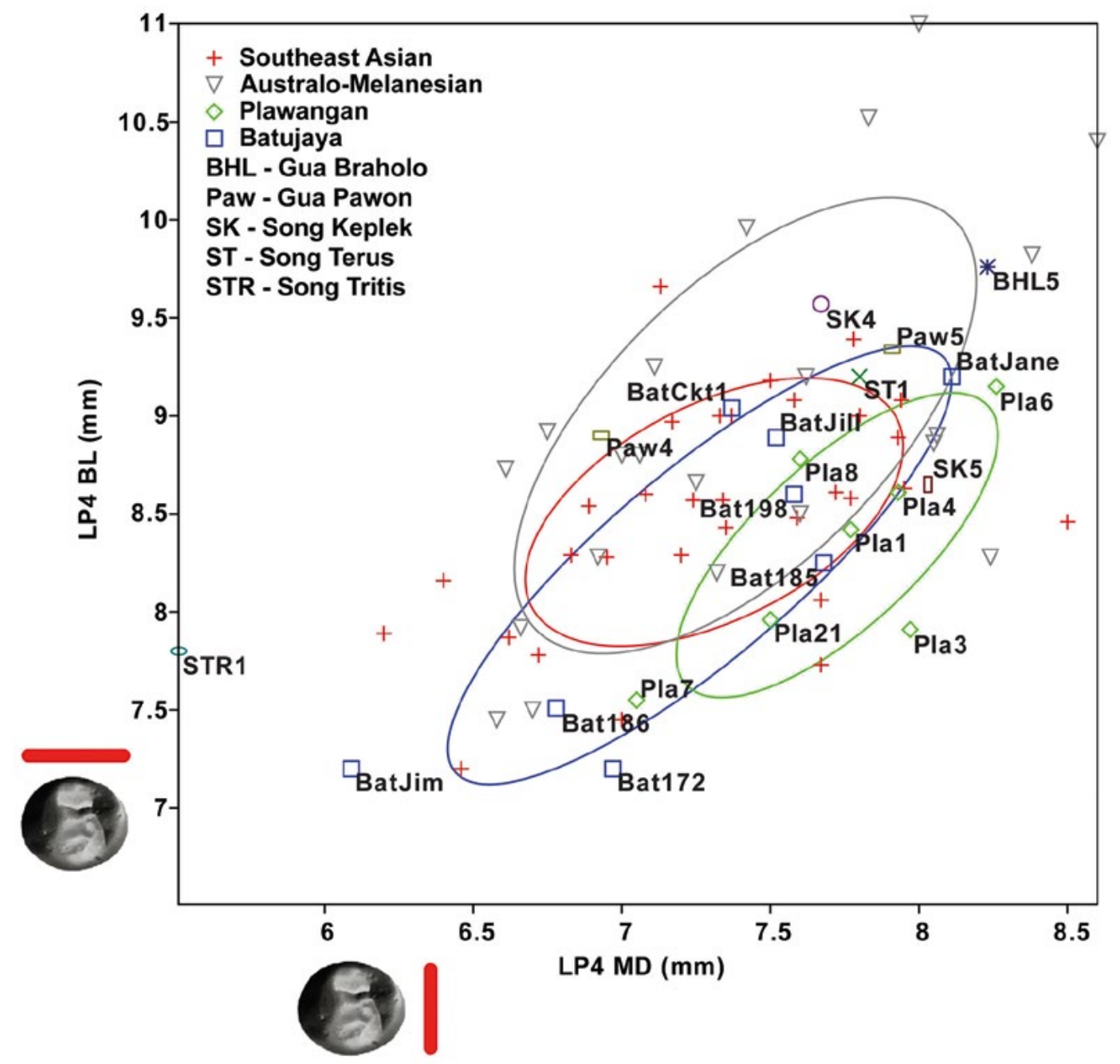

Figure 5.4 Bivariate plot of mesio-distal versus bucco-lingual measurements for $\mathrm{LP}_{4}$. Source: S. Noerwidi. 


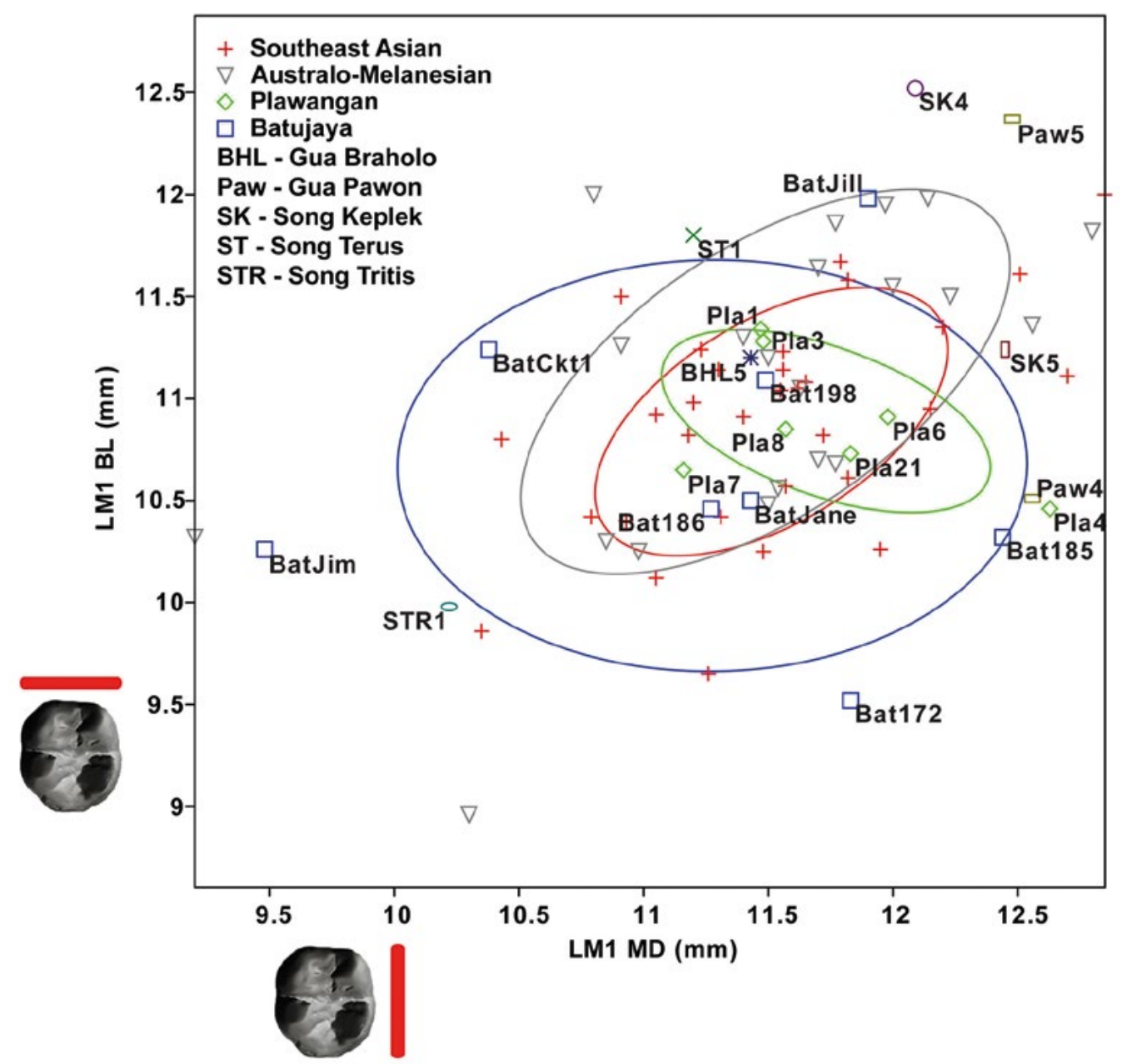

Figure 5.5 Bivariate plot of mesio-distal versus bucco-lingual measurements for $L M_{1}$.

Source: S. Noerwidi.

In contrast to their pre-Neolithic counterparts, the two Neolithic Java specimens have tooth diameters that are either typical by recent Southeast Asian standards (SK5) or small (STR1). STR1 from Song Tritus has remarkably small teeth, especially the lengths, which are consistently less than those recorded here for any recent Southeast Asian.

Finally, the Palaeometallic teeth from Batujaya and Plawangan are best described as similar in size to recent Southeast Asian teeth. Some show a tendency to be comparatively large, notably Pla6, which has lengths and/or breadths that put it outside of the recent Southeast Asian range except on its first molar. However, the specimens that possess remarkably small teeth, notably BatJim for whom the premolars and the first molar are smaller than those of any recent Southeast Asian recorded here, balance this. 


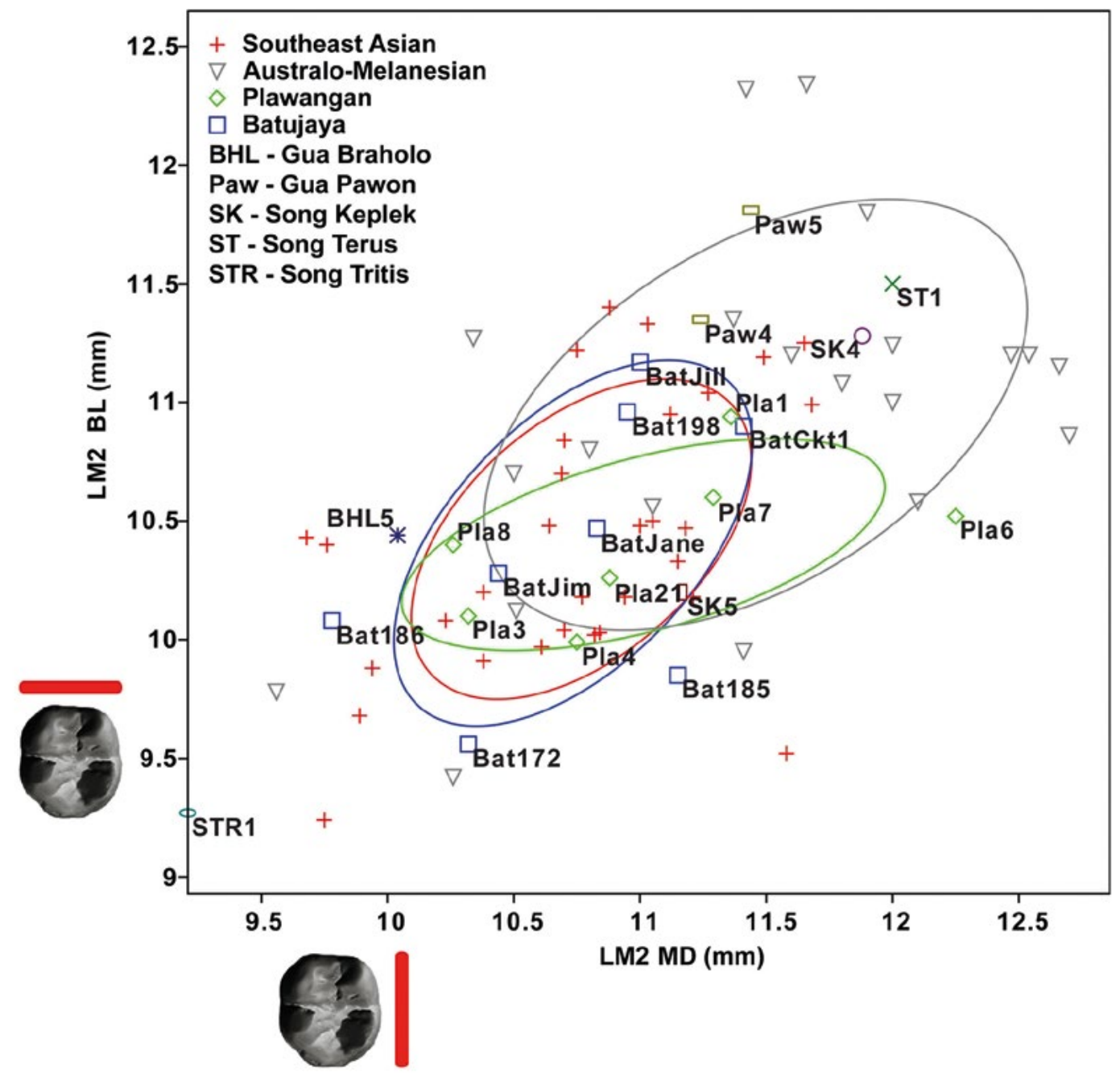

Figure 5.6 Bivariate plot of mesio-distal versus bucco-lingual measurements for $L M_{2}$.

Source: S. Noerwidi.

In summary, prediction 1 of Bellwood's Southern Mongoloid immigration scenario is clearly confirmed, due to the relatively large tooth size of recent Australo-Melanesians and especially the pre-Neolithic Java fossils compared with Neolithic and later specimens from Southeast Asia.

\section{Principal Components Analysis}

Before presenting the results from the PCA, we need to assess how many principal components (PCs) to include for analysis. A rule of thumb is to include all of the PCs with an eigenvalue greater than 1; that is, PCs that account for a larger proportion of the total variance than the average variance accounted for by the measurements originally entered into the PCA (Joliffe 2002). As there are eight measurements in the original data, the eigenvalues cumulatively sum to 8 , and for each of the eight PCs, the percentage it contributes to the total variance can be calculated (Table 5.2). 
Table 5.2 Eigenvalue and percentage of variance in PCA.

\begin{tabular}{|l|c|c|c|c|}
\hline $\mathbf{P C}$ & Eigenvalue & \% variance & Cumul. eigenvalue & Cumul. \% variance \\
\hline 1 & 4.04 & 50.50 & 4.04 & 50.50 \\
\hline 2 & 1.11 & 13.85 & 5.15 & 64.35 \\
\hline 3 & 0.85 & 10.56 & 5.99 & 74.91 \\
\hline 4 & 0.66 & 8.20 & 6.65 & 83.11 \\
\hline 5 & 0.44 & 5.56 & 7.09 & 88.67 \\
\hline 6 & 0.42 & 5.23 & 7.51 & 93.90 \\
\hline 7 & 0.31 & 3.85 & 7.82 & 97.75 \\
\hline 8 & 0.18 & 2.25 & 8.00 & 100.00 \\
\hline
\end{tabular}

Source: S. Noerwidi.

PC1 accounts for about half of the total variance, while PC2 and PC3 together account for about half of the remaining half. The decision was made to include all of PC1 to PC3 for analysis even though PC2 and PC3 are marginal in terms of the rule of thumb stated by Joliffe (2002).

Table 5.3 presents the loadings that the eight measurements have on each of the eight axes (PCs). All of the loadings are positive on Axis 1, which shows that PC1 is a size component that usefully summarises overall tooth size. Axis 2 has negative loadings on all of the bucco-lingual breadths and positive loadings on all of the mesio-distal lengths, except for the second molar length, which has a negative loading. Thus, the overall distinction is drawn between relatively short, broad teeth (registered by a negative PC2 score) and relatively narrow teeth (registered by a positive PC2 score). As noted previously, advancing interstitial wear tends to shorten teeth, decreasing the value of a positive PC2 score or making a negative PC2 score more strongly negative. Finally, Axis 3 has negative loadings on the premolar diameters and positive loadings on the molar diameters. Accordingly, a positive PC3 score registers a specimen with relatively large molars while a negative PC3 score registers a specimen with relatively large premolars.

Table 5.3 Value number of PCA correlation.

\begin{tabular}{|l|c|c|c|c|c|c|c|c|}
\hline & Axis 1 & Axis 2 & Axis 3 & Axis 4 & Axis 5 & Axis 6 & Axis 7 & Axis 8 \\
\hline$P_{3} M D$ & 0.34 & 0.46 & -0.25 & 0.19 & 0.54 & -0.58 & 0.02 & -0.08 \\
\hline$P_{3} B L$ & 0.38 & -0.09 & -0.46 & 0.13 & -0.01 & 0.35 & -0.70 & 0.04 \\
\hline$P_{4} M D$ & 0.36 & 0.21 & -0.06 & 0.50 & -0.68 & -0.15 & 0.09 & 0.15 \\
\hline$P_{4} B L$ & 0.38 & -0.16 & -0.45 & -0.13 & -0.01 & 0.37 & 0.69 & -0.05 \\
\hline$M_{1} M D$ & 0.28 & 0.38 & 0.61 & -0.45 & 0.13 & 0.35 & -0.09 & 0.24 \\
\hline$M_{1} B L$ & 0.40 & -0.23 & 0.25 & -0.50 & -0.29 & -0.31 & -0.12 & -0.59 \\
\hline$M_{2} M D$ & 0.31 & -0.47 & 0.37 & 0.45 & 0.36 & 0.31 & 0.08 & -0.32 \\
\hline$M_{2} B L$ & 0.36 & -0.55 & 0.25 & -0.16 & 0.09 & -0.27 & 0.05 & 0.67 \\
\hline
\end{tabular}

Source: S. Noerwidi.

A strong positive score for PC1 reflects large teeth overall, while a strong negative score reflects small teeth overall. Thus, PC1 in Figures 5.7 and 5.8 shows the great variability of AustraloMelanesians in their tooth size, with some specimens presenting larger teeth than those recorded for any recent Southeast Asian but other specimens presenting teeth as small as those of any recent Southeast Asian. As for the pre-Neolithic Java specimens, three (Paw5, SK4 and ST1) resemble the larger-toothed of the Australo-Melanesians in overall tooth size, and lie beyond the recent Southeast Asian range. BHL5 also has large teeth, at the upper limit of the recent Southeast Asian range, whereas Paw4 is typical by recent Southeast Asian standards. The Neolithic and later Java specimens together show a variability, which matches that of recent Southeast Asians on PC1, except STR1 and BatJim (Batujaya) whose overall tooth size is slightly smaller than that of any of the recent Southeast Asians recorded here 


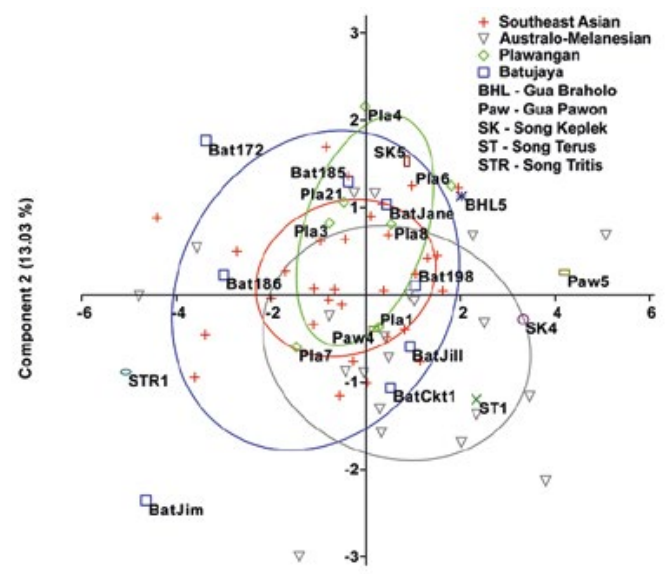

Component 1 (53.03\%)

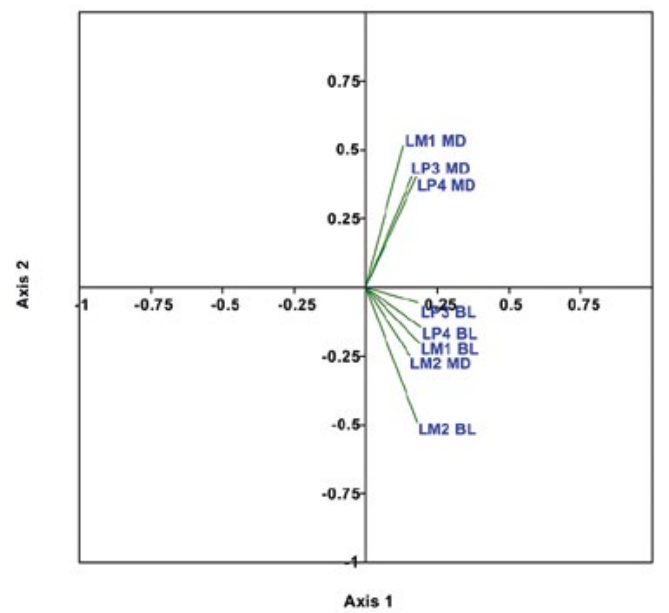

Figure 5.7 Biplot Graph of PC 1-2 for $\mathrm{LP}_{3}-\mathrm{LM}_{2}$ and Map of Axis 1 versus Axis 2. Source: S. Noerwidi.
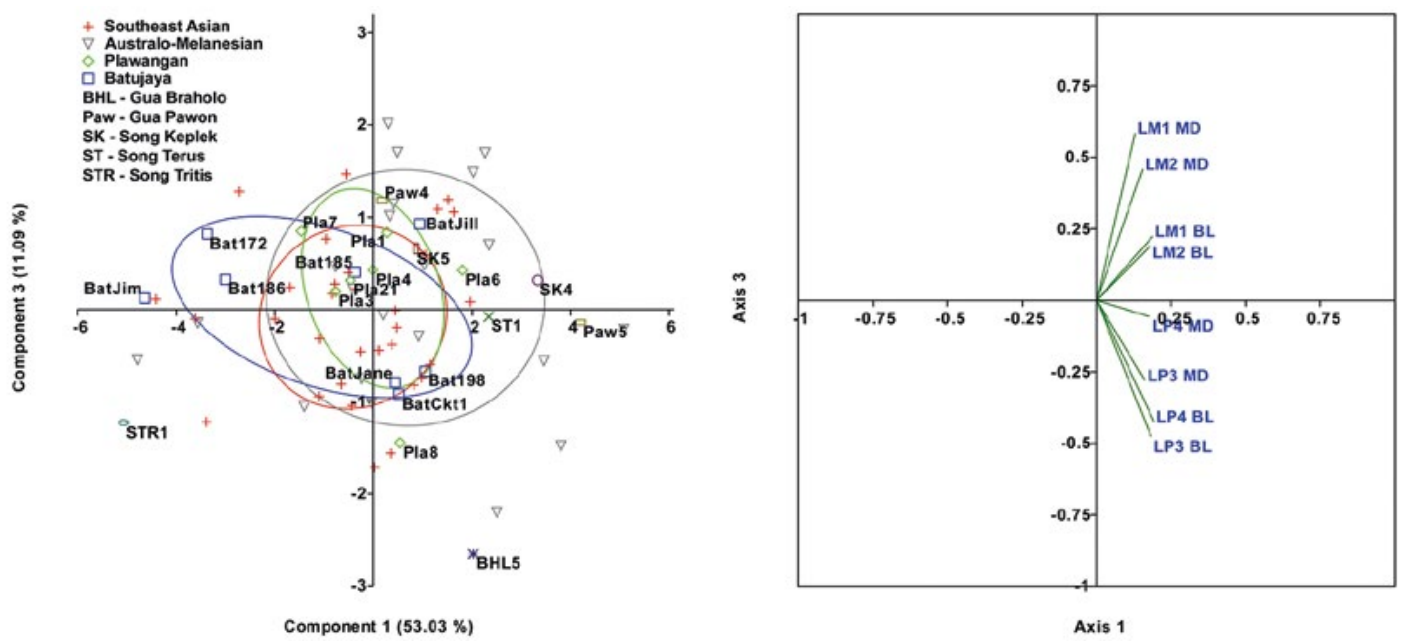

Figure 5.8 Biplot Graph of PC 1-3 for $\mathrm{LP}_{3}-\mathrm{LM}_{2}$ and Map of Axis 1 versus Axis 3. Source: S. Noerwidi.
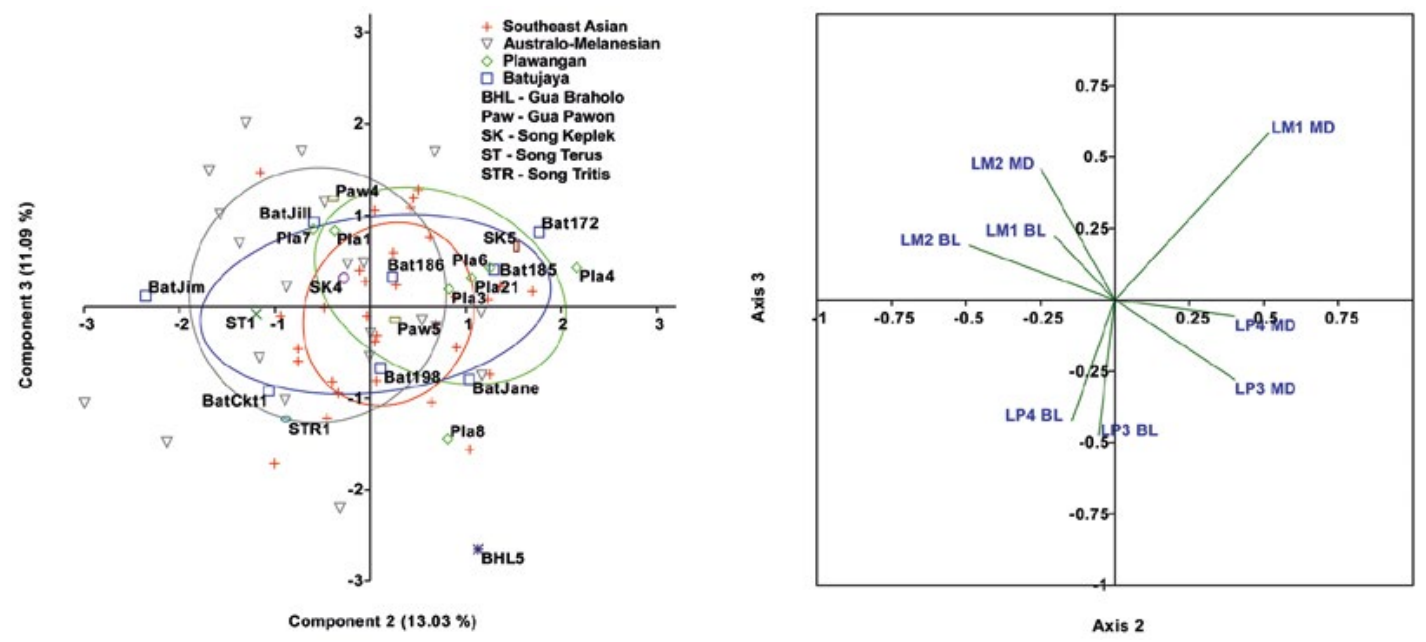

Figure 5.9 Biplot Graph of PC 2-3 for $L P_{3}-L_{2}$ and Map of Axis 2 versus Axis 3.

Source: S. Noerwidi. 
The graphs that include PC2 (Figures 5.7 and 5.9) reveal a moderate degree of overlap of Australo-Melanesians and recent Southeast Asians in their PC2 scores. However, some of the former are distinct from the latter on account of their relatively broader teeth and, conversely, some recent Southeast Asians have relatively more narrow teeth than recorded here for any Australo-Melanesian. The Batjim specimen has the relatively broad teeth otherwise shown only by Australo-Melanesians and falls well away from recent Southeast Asians in this regard. On the other hand, Pla4 (Plawangan) has slightly more narrow teeth (relatively speaking) than recorded here for any recent Southeast Asian.

The graphs that include PC3 (Figures 5.8 and 5.9) suggest extensive overlap between AustraloMelanesians and recent Southeast Asians in their PC3 scores, distinguished only by AustraloMelanesians' greater variability. The Pre-Neolithic BLH5 fossil has unusually large premolars compared to its molar size, and so is distinguished from every other specimen on its strongly negative PC3 score.

In summary, PC1 demonstrates a larger tooth size for three to four of the pre-Neolithic Java fossils (Paw5, SK4, ST1, and marginally BLH5) than recorded for any of the Neolithic to recent Java and Malay specimens. Similarly large teeth are otherwise recorded only amongst AustraloMelanesians. This result clearly confirms prediction 2 of Bellwood's Southern Mongoloid immigration scenario. The inferences that can be drawn from the shape comparisons (PC2 and PC3) are more equivocal and cannot reasonably be stated as confirmation of Bellwood's prediction 3. However, this may be because such a large proportion of the total variance - just over half - is explained by overall tooth size, whereas both PC2 and PC3 are of marginal value for retention in the PCA presented here.

\section{Cluster analysis}

The cluster analysis (Figure 5.10) identified three main clusters. Cluster 1 includes specimens with large teeth, whereas clusters 2 and 3 include specimens with middle-sized and small teeth respectively. These summary descriptions of the clusters are clear from which of the previously discussed Java archaeological specimens are found in which cluster, and from the particular importance of size (rather than any shape aspect) in accounting for the measurements' variability (see PCA results, above). Clusters 1 and 2 join with each other before an isolated Australian specimen joins this super-cluster, with the final join made by Cluster 3 .

Cluster 1 includes 10 specimens, four pre-Neolithic Java fossils (SK4, Paw5, ST1 and BLH5) and six Australo-Melanesians (interestingly, all from Tasmania and the Solomon Islands). While one pre-Neolithic Java fossil (Paw4) is included in Cluster 2, so are 12 Australo-Melanesians, four of them in the same sub-cluster as Paw4. Accordingly, the tooth-size difference between Paw4 and the other pre-Neolithic Java fossils is hardly indicative of different 'racial groups', but is instead consistent with the expected tooth-size variability to be found within a single group.

The 52 specimens with middle-sized teeth assigned to Cluster 2 include the majority (26) of the 30 recent Southeast Asians, just over half of the Batujaya specimens (5/8), all seven Plawangan specimens and SK5. Notwithstanding the inclusion of 12 Australo-Melanesians, noted above, Cluster 2 is predominantly a Southern Mongoloid cluster, suggesting that this status applies to SK5.

The 11 small-toothed specimens in Cluster 3 include three of the eight Batujaya specimens, STR1, five recent Southeast Asians and two Australo-Melanesians. The quite strong representation of Batujaya specimens in this cluster suggests a possible role of India as a source for very small-toothed immigrants to Java. The smaller tooth size of Indians compared with Southern Mongoloids is demonstrated by Hanihara (2005: Figure 1). However, this could not be an explanation for the very small teeth of STR1, whose antiquity predates Indian influence on Java, or the two AustraloMelanesians whose very small teeth were also apparent from the PCA. 
In summary, the cluster analysis results confirm prediction 4 of Bellwood's Southern Mongoloid immigration scenario. They reveal a cluster of large-toothed specimens restricted to pre-Neolithic Java and Australo-Melanesians, and a cluster of specimens with middle-sized teeth dominated by Neolithic to recent Java and Malay specimens. The latter cluster also includes the pre-Neolithic Java Paw5 fossil and 12 of the 21 Australo-Melanesians, reflecting some combination of the inclusion of small-toothed females in the analysis and intraracial tooth-size variability unrelated to sexual dimorphism.

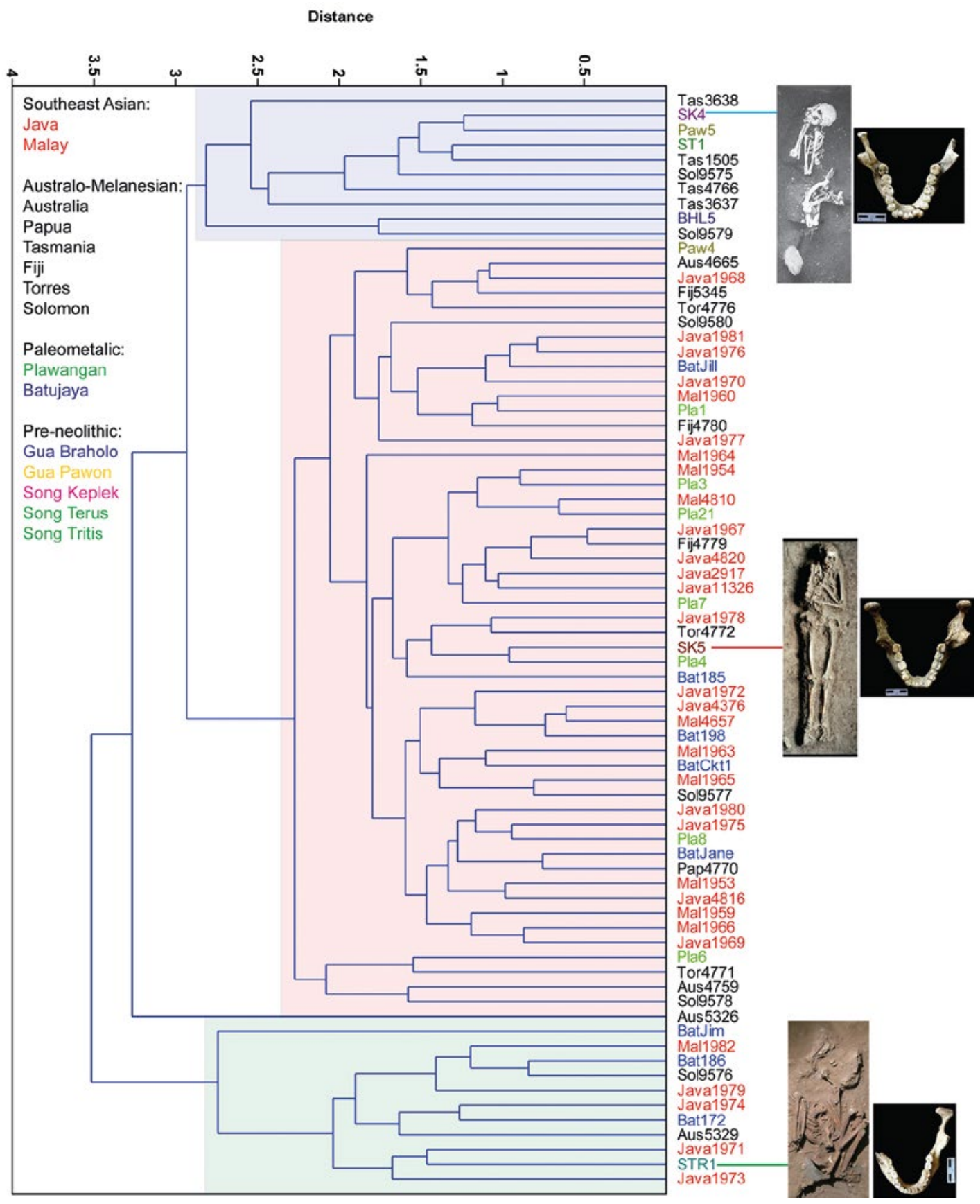

Figure 5.10 Cluster analysis on $\mathrm{LP}_{3}-\mathrm{LM}_{2}$ from all specimens by Euclidean Distance Method.

Source: S. Noerwidi. 


\section{Discussion}

Java was part of the Pleistocene subcontinent of Sundaland and its human fossil record has long attracted the attention of anthropologists interested in the colonisation of the region. Initial occupation of Java by Homo erectus occurred almost two million years ago. The multiregional hypothesis on modern human origins proposed a deeply rooted ancestry of Australo-Melanesians in Java Homo erectus, whereas the ultimate roots of the Mongoloids lay with Homo erectus in China (see Wolpoff 1999). There has been an accumulation of fossil and genetic evidence for the Late Pleistocene origins of anatomically modern humans in Africa, leading to widespread rejection of the multiregional hypothesis, but not of all of the associated concepts. For instance, the colonisation of Australia and Melanesia would have occurred via Sundaland, undertaken by colonists with Australo-Melanesian biological affinities. And according to the 'two-layer hypothesis', the populations across Southeast Asia retained these Australo-Melanesian affinities until approximately $4000 \mathrm{BP}$, when there was a southward expansion of Mongoloid populations from the early agricultural heartlands of southern and central China (Matsumura and Oxenham 2014). Bellwood's (1997) hypothesised expansion of Austronesian-speaking Southern Mongoloids from Taiwan across ISEA after $4000 \mathrm{BP}$ represents the component of the two-layer hypothesis relevant to Java's population history.

The dental metrical analysis performed here is consistent with the points described above. There is a basic distinction between the pre-Neolithic Java fossils, with tooth sizes otherwise recorded for Australo-Melanesians, and the Neolithic and Palaeometallic specimens with tooth sizes similar to those of recent Southeast Asians. The 'Australo-Melanesian' dentitions in Java are dated to contexts spanning the terminal Pleistocene (BHL5) and Pleistocene-Holocene boundary (Paw5) to the early Holocene (ST1) and mid-Holocene, ca. 5000 cal. BP (SK4). One of the pre-Neolithic Java fossils (Paw4) cannot be distinguished from recent Southeast Asians on the basis of tooth size, but this is also the case with many Australo-Melanesians. The 'Southern Mongoloid' archaeological dentitions in Java include the SK5 and STR1 Neolithic specimens dated to approximately 3000 BP, and the Batujaya and Plawangan specimens dated to approximately 2000 BP. None of these dentitions are large by recent Southeast Asian standards, and their variability is expressed in the particularly small tooth size of STR 1 and some of the Batujaya specimens. In summary, the tooth-size results clearly confirm Bellwood's 'Out-of-Taiwan' scenario.

As observed in the Introduction, Karafet et al. (2010) have proposed a more complicated population history for ISEA that would have involved four colonisation events, two in the Late Pleistocene and two in the late Holocene. However, the data and analytical framework employed in the present study do not allow for a test of the scenario of two Late Pleistocene colonisation events. This is because both events would have involved Australo-Melanesians, and so the Australo-Melanesian affinity of the pre-Neolithic Java fossils would be the expected consequence of either event. On the other hand, there is the potential to test for a protohistorical influence from India, as proposed by Karafet et al. (2010), on top of the Neolithic immigration from Taiwan. The cluster of specimens with very small teeth (Cluster 3 in Figure 5.10) includes an unexpectedly high proportion from Batujaya and none from Plawangan. The difference between these two burial populations, which are geographically and chronologically close, suggests an exogenous genetic contribution to Batujaya, consistent with the site's Indian cultural influences as recorded archaeologically (Manguin and Indradjaja 2011). If there had been an exogenous genetic influence on the Plawangan population, it may have been from northern Vietnam during the early centuries AD. According to Bintarti (2000), Dong Son (protohistorical northern Vietnam) cultural influences can be seen on the Plawangan mortuary assemblage. In this context, it is worth noting that Dong Son Vietnamese tooth size was comparable to that of recent Javanese and Malays (Matsumura and Hudson 2005).

\section{terra australis 45}



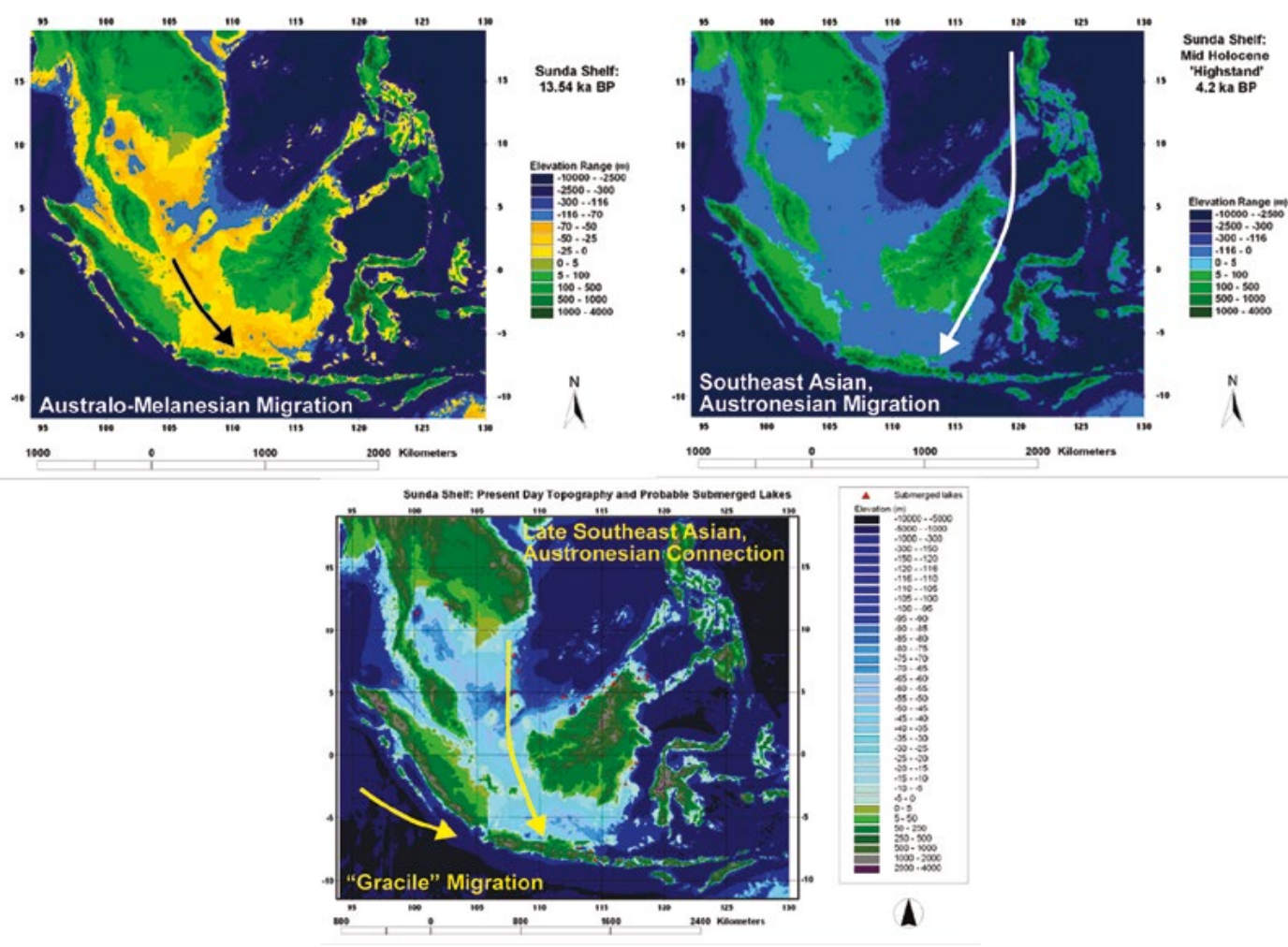

Figure 5.11 The multiple migrations hypothesis: Australo-Melanesian (Latest Pleistocene), Southeast Asian or 'Southern Mongoloid' (Austronesian, 3000 BP), and 'gracile' (early AD, perhaps from India). Map sources: Sathiamurthy and Voris 2006.

These suggested protohistorical contributions to the recent Javanese gene pool can be regarded as elaborations of the 'two-layer hypothesis'. Note also that proponents of this hypothesis envisage the persistence of the Australo-Melanesian substratum till today amongst the populations of ISEA, albeit to varying degrees, rather than complete replacement by the immigrant Mongoloids. Jacob (1967), Bellwood (1997: 92), Matsumura and Hudson (2005), Hanihara (2006: 100), Matsumura et al. (2011) and Matsumura and Oxenham (2014), amongst others, have all advocated dual inheritance. Further, based on his study of the Gunung Sewu and other ISEA fossil skulls, Détroit (2002) proposed that ISEA has long been an inter-population hybridisation zone', with more complex population movements during the pre-Neolithic than the blanket term 'Australo-Melanesian' necessarily conveys. While Détroit's proposal was partly based on the early Holocene dating of SK5 that he had at his disposal - a dating that has now been revised to around $3300 \mathrm{cal}$. BP - it is consistent with the proposal by Karafet et al. (2010) of a terminal Pleistocene colonisation event from what is now Mainland Southeast Asia into Sundaland.

\section{Conclusions}

The Java archaeological specimens covered here correspond in time to the terminal Pleistocene to late Holocene colonisation events proposed by Karafet et al. (2010), and analysis produces compatible results (see Figure 5.11). Their Layer B would have involved a terminal Pleistocene, migration overland from the north by populations with Australo-Melanesian affinities. The preNeolithic Java fossils show large teeth overall, which is more an Australo-Melanesian than a Southern Mongoloid trait. Their Layer C corresponds to the 'Out-of-Taiwan', Mongoloid migration, which is the hallmark of the 'two layer hypothesis' in an ISEA context. The Neolithic 
and Palaeometallic Java specimens all demonstrate small to moderate tooth size, which characterises recent Southeast Asians. This study confirms that Song Keplek 5 has premolar and molar dimensions that place it within Layer C, grouped with those individuals with Southern Mongoloid dental traits. Finally, their Layer D includes protohistorical genetic contributions on ISEA from India and northern Vietnam, and the first of these may be reflected in the particularly small teeth of several Batujaya specimens. The results of the present analysis are particularly strong in their support for Bellwood's 'Out-of-Taiwan' scenario, including his view that a considerable Australo-Melanesian genetic inheritance has persisted across ISEA.

\section{Acknowledgements}

The author acknowledges the advice of Peter Bellwood on the 'Out-of-Taiwan' hypothesis and his help in utilising the IPPA-Arizona AMS Outreach Program to obtain a direct date on the Song Keplek 5 burial (provided by Greg Hodgkins of the NSF-Arizona AMS Laboratory). He also thanks his supervisors Florent Détroit, Dominique Grimaud-Hervé, Truman Simanjuntak, Harry Widianto and François Sémah for their advice on the archaeological sites. Thanks are also due to Truman Simanjuntak, Harry Widianto, Etty Indriaty, Rusyad Adi Suriyanto, PierreYves Manguin, Lutfi Yondri, Siswanto and Desril Riva Shanti for permission to record the Java archaeological dental remains.

\section{References}

Bellwood, P. 1995. Austronesian prehistory in Southeast Asia: Homeland, expansion and transformation. In P. Bellwood, J.J. Fox and D. Tryon (eds), The Austronesians: Historical and Comparative Perspectives, pp. 96-111. Canberra: The Australian National University.

- 1997. Prehistory of the Indo-Malaysian Archipelago. 2nd edition. Hawai' i: University of Hawaii Press.

Bintarti, D.D. 2000. More on urn burials in Indonesia. Indo-Pacific Prehistory Association Bulletin 19: 73-76.

Blust, R. 1976. Austronesian culture history: some linguistic inferences and their relations to the archaeological record. World Archaeology 8: 19-42. doi.org/10.1080/00438243.1976.9979650.

Bronk Ramsey, C. 2014. Oxcal 4.2 manual. c14.arch.ox.ac.uk/oxcal.html.

Brown, P. 1989. Coobool Creek: A Morphological and Metrical Analysis of the Crania, Mandibles and Dentitions of a Prehistoric Australian Human Population. Terra Australis 13. Canberra: The Australian National University.

Chambers, G.K. 2006. Polynesian genetic and Austronesian prehistory. In T. Simanjuntak, I.H.E. Pojoh and M. Hisyam (eds), Austronesian Diaspora and the Ethnogenesis of People in Indonesian Archipelago, pp. 299-319. Jakarta: LIPI Press.

Détroit, F. 2002. Origine et évolution des Homo sapiens en Asie du Sud-Est: Descriptions et analyses morphométrique de nouveaux fossils. Unpublished PhD thesis, Muséum National d'Histoire Naturelle, Paris.

Hanihara, T. 2005. Metric dental variation of major human populations. American Journal of Physical Anthropology 128: 287-298. doi.org/10.1002/ajpa.20080. 
2006. Interpretation of craniofacial variation and diversification of East and Southeast Asians. In M. Oxenham and N. Tayles (eds), Bioarchaeology of Southeast Asia, pp. 91-111. Cambridge: Cambridge University Press. doi.org/10.1017/CBO9780511584220.006.

Holland, S.M. 2006. Cluster analysis. strata.uga.edu/6370/lecturenotes/clusterAnalysis.html.

Jacob, T. 1967. Some Problems Pertaining to the Racial History of the Indonesian Region. Utrecht: Bureau of Technical Assistance.

Joliffe, I.T. 2002. Principal Component Analysis. 2nd edition. New York: Springer.

Karafet, T.M., H. Brian, P.C. Murray, H. Sudoyo, S. Downey, J.S. Lansing and M.F. Hammer. 2010. Major east-west division underlies Y chromosome stratification across Indonesia. Molecular Biology and Evolution 27: 1833-1844. doi.org/10.1093/molbev/msq063.

Manguin, P.-Y. and A. Indradjaja. 2011. The Batujaya site: new evidence of early Indian influence in West Java. In P.-Y. Manguin, A. Mani and G. Wade (eds), Early Interactions between South and Southeast Asia, pp. 113-136. Singapore: Southeast Asian Studies.

Matsumura, H. and M.J. Hudson. 2005. Dental perspectives on the population history of Southeast Asia. American Journal of Physical Anthropology 127: 182-209. doi.org/10.1002/ajpa.20067.

Matsumura, H. and M.F. Oxenham. 2014. Demographic transitions and migration in prehistoric East/ Southeast Asia through the lens of nonmetric dental traits. American Journal of Physical Anthropology 155: 45-65. doi.org/10.1002/ajpa.22537.

Matsumura, H., M.F. Oxenham, K.T. Nguyen, L.C. Nguyen, and K.D. Nguyen. 2011. The population history of mainland Southeast Asia: Two layer model in the context of northern Vietnam. In N. Enfield (ed.), Dynamics of Human Diversity: The Case of Mainland Southeast Asia, pp. 153-178. Canberra: Pacific Linguistics.

Noerwidi, S. 2011/12. The Significance of the Holocene Human Skeletal Song Keplek 5 in the History of Human Colonization of Java: A Comprehensive Morphological and Morphometric Study. Master Erasmus Mundus en Quaternaire et Préhistoire. Paris: Muséum National d'Histoire Naturelle. hopsea. mnhn.fr/pc/thesis/M2\%20Noerwidi_S.pdf.

Pietrusewsky, M. 2006. The initial settlement of Remote Oceania: The evidence from physical anthropology. In T. Simanjuntak, I.H.E. Pojoh and M. Hisyam (eds), Austronesian Diaspora and the Ethnogenesis of People in Indonesian Archipelago, pp. 320-347. Jakarta: LIPI Press.

Reynolds, T., G. Barker, H. Barton, G. Cranbrook, L. Farr, C. Hunt, L. Kealhofer, V. Paz, A. Pike, P.J. Piper, R.J. Rabett, G. Rushworth, C. Stimpson and K. Szabó. 2013. The first modern humans at Niah, c. 50,000-35,000 years ago. In G. Barker (ed.), Rainforest Foraging and Farming in Island Southeast Asia, pp. 135-172. Cambridge: McDonald Institute for Archaeological Research.

Sathiamurthy, E. and H.K. Voris. 2006. Maps of Holocene sea level transgression and submerged lakes on the Sunda Shelf. The Natural History of Chulalongkorn University Supplement 2: 1-43.

Sémah, F., A-M. Sémah, C. Falguères, F. Détroit, X. Gallet, S. Hameu, A-M. Moigne, and H.T. Simanjuntak. 2004. The significance of the Punung karstic area (eastern Java) for the chronology of the Javanese Palaeolithic, with special reference to the Song Terus cave, Mod. Quaternary Research in Southeast Asia 18: Quaternary Research In Indonesia, pp. 45-62. Leiden: A.A. Balkema

Sémah, F., A.-M. Sémah and M. Chacornac-Rault. 2006. Climate and continental record in Island South East Asia since the Late Pleistocene: Trends in current research, relationship with the Holocene human migration wave. In T. Simanjuntak, I.H.E. Pojoh and M. Hisyam (eds), Austronesian Diaspora and the Ethnogenesis of People in Indonesian Archipelago, pp. 15-29. Jakarta: LIPI Press. 
Simanjuntak, T. (ed.). 2002. Gunung Sewu in Prehistoric Times. Yogyakarta: Gadjah Mada University Press.

Snell, C.A.R.D. 1949. Human skeletal remains from Gol Ba’it, Sungai Siput, Perak, Malaya Peninsula. Acta Neerlandica Morphologica Normalis et Pathologicae 6: 353-377.

Solheim, W.G.II. 2006. Archaeology and Culture in Southeast Asia: Unraveling the Nusantao. Quezon City: The University of Philippines Press.

Storm, P., F. Aziz, J. de Vos, D. Kosasih, S. Baskoro, Ngaliman and L.W. van den Hoek Ostende. 2005. Late Pleistocene Homo sapiens in a tropical rainforest fauna in East Java. Journal of Human Evolution 49: 536-545. doi.org/10.1016/j.jhevol.2005.06.003.

Storm, P., R. Wood, C. Stringer, A. Bartsiokas, J. de Vos, M. Aubert, L. Kinsley and R. Grün. 2013. U-series and radiocarbon analyses of human and faunal remains from Wajak, Indonesia. Journal of Human Evolution 64: 356-365. doi.org/10.1016/j.jhevol.2012.11.002.

Westaway, K.E., M.J. Morwood, R.G. Roberts, A.D. Rokus, J.-X. Zhao, P. Storm, F. Aziz, G. van den Burgh, P. Hadi, Jatmiko and J. de Vos. 2007. Age and biostratigraphic significance of the Punung rainforest fauna, East Java, Indonesia, and implications for Pongo and Homo. Journal of Human Evolution 53: 709-717. doi.org/10.1016/j.jhevol.2007.06.002.

Widianto, H. 2001. Laporan Penelitian Song Tritis. Laporan Penelitian Arkeologi. Yogyakarta: Balai Arkeologi.

2006. Austronesia prehistory from the perspective of skeletal anthropology. In T. Simanjuntak, I.H.E. Pojoh and M. Hisyam (eds), Austronesian Diaspora and the Ethnogenesis of People in Indonesian Archipelago, pp. 174-185. Jakarta: LIPI Press.

Wolpoff, M.H. 1999. Paleoanthropology. 2nd edition. Boston: McGraw-Hill. 
This text is taken from New Perspectives in Southeast Asian and Pacific Prehistory, edited by Philip J. Piper, Hirofumi Matsumura and David Bulbeck, published 2017 by ANU Press, The Australian National University, Canberra, Australia. 